
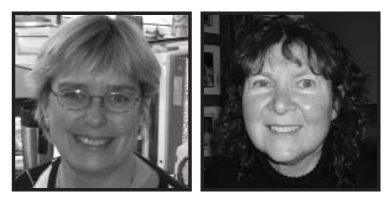

\title{
Building Leadership Capacity Among Student Teachers: A Narrative Inquiry Into Relational Continuity in Student Teachers' Field Placements
}

Sue McKenzie-Robblee, Crestwood Elementary Junior High School Pam Steeves, University of Alberta

\section{ABSTRACT}

The authors of this paper are two teacher researchers, one situated at the university and one situated as principal of an elementary school. Through narrative inquiry (Clandinin and Connelly, 2000) two main themes of belonging and becoming were illuminated. The work suggests trusting relationships evolving from dialogue sustained over two field placements at the same school offer student teachers the possibilities of connecting their life experiences with their new experiences at the school; a connected knowing that enables them to develop their identifies as beginning teachers.

"Their story, yours, mine-it's what we all carry with us on this trip we take, and we owe it to each other to respect our stories and learn from them" (Coles, 1989, p. 30.).

\section{Linda's Story}

nother group of student teachers is coming to school today. I wonder who they are and what the next nine weeks will bring as we establish a thread in our school tapestry. This re-presentation of our year together will now include these student teachers and the relationships that they create as they become connected with within our community. 
It seems a little strange because this is the first cohort that I have not had some involvement with prior to this very first meeting. I'm always excited, it feels just like the beginning of a new school year to discover where the journey may take us and what connections and experiences may evolve. The promise of new relationships, wonders, hopes and fears!

I'm not sure what to do. One of our student teachers seems to be struggling and we've barely begun. She speaks in such positive terms about her dream of becoming a teacher and the faith that her family has in her abilities to achieve this dream. I'm worried. Her voice alone has me wondering what is her story? Where has she come from? What are her challenges as she sees them? What can I do to help? To shape? To support?

I've had a long conversation with her mentor teacher. I've asked to observe a lesson and watch her interactions with the children because her actions and perceptions of those actions aren't matching. I need a context to be able to speak with her. She hasn't been able to connect with the children. She doesn't talk with them about their lives. The children are not a part of her daily interactions. The children don't know her. The children aren't responding.

That was a really hard conversation. Linda thinks that she has made such great gains since last time. We are nearly at the end of week three. What last time? I now know that this is the second and final time that Linda has to be successful in this practicum course. She took it before and withdrew on the advice of the University. She has spoken with a counselor; she has taken courses to help with her abilities to respond to developing situations around her, her social skills and her ability to do more that one thing at a time! She has taken a year off! Now what? She is crying and saying that the things that I shared and asked her to think about and to find different ways of working with the children were all things that she's heard before. Linda thought that she was doing so much better! Her hope for success was keeping her coming to school everyday to try and try again. Her Mom knows that she can do it this time. Her husband tells her that her faith will help her. But how do I help her? She wants another opportunity to show me.

Another lesson, this time the children are being patient but not engaged. They are quietly doing their own things, not what Linda is asking for. They are confused and don't really know what she wants. Her voice is lost in the activity of the room. Royce has a problem and leaves the classroom. Linda doesn't stop her lesson. The children wonder what has happened to him. They ask. She doesn't stop "teaching." 
I feel terrible and I'm not looking forward to the next conversation. We need to present Linda with a notification of concern. She won't be able to make the changes necessary. She will be devastated! Why wasn't I given a chance to help her? If I had known Linda's story before she came to our school there may have been things that I could have done differently. Why did we-the school, the mentor teacher, the children, the University Facilitator-have to find out the "hard" way? The dignity and grace for Linda as a person was not threaded through the whole experience.

I call Linda at home a few days later. She cries and says in a halting voice that she is okay and needs time. Her family doesn't understand what happened. My heart goes out to her. Where and when did the "system" value the storied life that we were asked to participate in?

The damage control and repair work at school now occupies my thoughts ... I don't feel that I was given a chance to help. The system didn't work for Linda, for our school, for our children.

Linda's story troubles us. As we each compose our lives as educators, we wonder if there are other ways to imagine the field placement experience for student teachers. Teaching may not have been Linda's chosen profession, but an educative experience for Linda was never offered. We wonder if Linda's experience could lead to a place of possibilities rather than a place that ends in failure? And whose failure is it? This paper develops from a narrative inquiry into the continuity of student teachers' experiences in field placements. For us, a teacher educator researcher and a teacher educator principal, it is a story of possibility when becoming a teacher in a school grows from an evolving sense of belonging to a school.

\section{Research Purpose}

A fundamental purpose of teacher education is to allow student teachers opportunities to develop a professional identity as teachers. In narrative terms, Connelly and Clandinin conceptualize teachers' experience of identity as composed of "stories to live by" (1999). Our understanding of stories to live by are that these stories are those that dwell in a person's heart, that a person is committed to and those that a person composes. Becoming a teacher implies developing new stories to live by. Connelly and Clandinin (1999) further conceptualized developing and living out stories to live by as being shaped by school landscapes, a metaphorical space filled with diverse people, places and things in continual interaction. As student teachers 
begin their transition from students to teachers, they need safe supported spaces on the landscape where stories reflecting newly reconfigured teacher identities can be told. Due to the complexity of the school landscape, a significant period of time may be necessary to make possible a belonging place where hopeful relational spaces can develop (Steeves, 2000). How might a relationship created through dialogue over a significant period of time on one school landscape shape the student teachers' understanding of themselves as becoming teachers? How might narrative inquiry methodologies have the potential to offer a deeper understanding of what it means to become a teacher?

With these wonders in mind, we sought to inquire into the experiences of student teachers engaging in two successive field experience placements in one particular school community.

\section{Situating the Inquiry}

Our interest for student teachers was to create a safe relational space for growth during their field placement experience. Dewey, 1938 affirms a plethora of experiences does not lead naturally to education. It is not what but how experiences happen which is important. Situations that give people the opportunity to make connections to their life are deemed worthy because there is the opportunity for continuity of learning and a continuing sense of self. He wrote the following:

Continuity and interaction in their active union with each other provide the measure of the educative significance and value of an experience. The immediate and direct concern of an educator is then with the situations in which interaction takes place. (p. 45)

Affirming Dewey's (1938) philosophical stance around continuity of experience, we situated the inquiry within research literature which reflects a narrative view of teacher education. With Hollingsworth (1993) and others we hold that continuity of experience through a pedagogy of conversations sustained over time can lead beginning teachers to construct stories of becoming a teacher. Clandinin, Davies, Hogan and Kennard (1993) emphasized the evolving nature of such knowledge by saying "Conversations with theory, research, social conditions, different cultural groups, other teachers, and children allow for a response-filled environment and encourage more mindful retellings. These tellings and retellings are education" (p. 218). 
The kind of knowledge shaped in such sustaining spaces was described by Connelly and Clandinin (1988) as personal practical knowledge: "a moral, affective and aesthetic way of knowing life's situations" (p. 95). How might student teachers become teachers with a moral, affective and aesthetic way of knowing life's situations? How necessary might this way of knowing be to student teachers faced with the increasingly diverse classrooms in Canada today?

\section{Methodology}

"Narrative is the study of how humans make meaning of experience by endlessly telling and retelling stories about themselves that both refigure the past and create purpose in the future" (Connelly and Clandinin, 1988, p. 24).

This research was a narrative inquiry. Narrative inquiry is a kind of educational research grounded in relationship which develops over time. Narrative inquiry offers both the researcher and participant the opportunity to construct (tell) and reconstruct (retell) the experiences they are living. Connelly and Clandinin (1999) affirm that as new stories are lived and told, new stories to live by evolve continuously shaping identities.

We imagined developing rich insights into student teachers' experiences of becoming teachers through narrative inquiry. As such, prescribed agendas for our regularly scheduled conversations were not set but rather we encouraged student teachers to tell stories of their own lives, past and present while at the same time being shaped by their practicum experiences at the school. We listened and inquired alongside and together with the student teachers. We particularly noted present and past reflections as well as future imaginings. As students told and retold their experiences in this conversational way, we listened to the student teachers' as they developed their identities as beginning teachers.

The student teachers were drawn from an initial first year "Introduction to Teaching" course which was taught by us, a teacher educator and school principal as well as another teaching colleague from the university in a large city in Western Canada. Special permission was granted to teach the course at the principal's elementary school site. Typically, the course is offered on campus at the university. During the second and third year of their teacher education program, student teachers are given two field placements at two different schools, thus completing their 
introductory and advanced practicum terms. Again, on the basis of our proposed study we sought and received permission to have students from our school-based course attend their two practicum experiences at the same school if they wished.

The principal's reputation as a leader in the district school system helped in getting this permission from the administration at the university. One of our intentions with the cotaught "Introduction to Teaching" course held at the school was to give student teachers the opportunity to begin to develop a relationship with us as well as with the school community itself.

From our initial Introduction to Teaching course, we found three participants who were willing and able to complete both their Introductory Professional Term (IPT) field placement, a four-week full-time experience, as well as their Advanced Professional Term (APT) field placement, an eight-week full-time experience, at the same school in each of the following two years. The student teachers participated in weekly group conversations with us during the course of their two field placements at the school. Transcripts of group conversations and individual interviews were used as field texts.

The student teachers who remained a the same school for all their practicum placements were assigned to different cooperating teachers. Yet, because the multiple placements were all held at the same school, the student teachers were able to develop long-term relationships with many of the teachers along with the principal. The principal, Sue, a co-researcher in the study and Pam, a teacher educator and also a co-researcher in the study, were able to relate to the student teachers on multiple levels.

\section{Conversations as field texts}

The principal (co-researcher) was known by staff, students and family as readily approachable and so we chose to hold our conversation amidst, not apart from, the ever-moving and complex school landscape. We wanted student teachers to experience a broader sense of school. Accordingly, we gathered in Sue's office for our weekly conversations. As co-researchers, we were interspersed amongst the student teachers, squeezing up close on comfortable chairs around a circular office table. Student teachers were present as documents from central office were signed, as teachers came forward with pressing questions, as children and families dropped by. 
The three student teachers participated with us in a series of regularly scheduled, taped conversations around their unfolding school lives over the two field placements at the school. These conversations, held over time, offered a space for student teachers to reflect on and tell accounts of their teaching experiences. The student teachers shared reflections about their present experiences in the school, offered imaginings of their future experiences as teachers and told memories from their past and ongoing experiences as students. The events brought forward were ones they found significant to bring up, ones they were attending to as their teaching lives unfolded at the school.

As we engaged in conversation with the student teachers, we had the opportunity to join in the conversation during "teachable" moments. We often elaborated on their stories from practice with educational theory, then connected these back to practice and so on. As narrative inquirers, we imagined our contributions as "dabs of glue" as Paley (1986) would say, scaffolding newly connected threads of knowing amongst us all. It was practice first, then theory, situated within a storied school landscape.

\section{Interviews as field texts}

At the end of both the IPT and APT field placements at this particular school, the student teachers also participated in individual interviews to talk about how they connected their various learning activities in teacher education; to talk about their learning experiences over time; and to talk about what was helpful in their transition from students to beginning teachers. Because we were known to the student teachers, conversational interviews led readily to more reflection on their experiences. The interviews were held in Pam's university office.

\section{Composing Interim Texts-Found Poetry}

As mentioned earlier, field texts were gathered from transcribed group conversations and transcribed individual interviews. Soon after, interim texts were composed and shared with participants to give us some response and direction as we created our research texts (Clandinin and Connelly, 2000). Found poetry was composed from transcripts of interviews held with each student teacher individually at the end of the first IPT field placement. Found poetry (Butler-Kisber, 1998) was created from actual words uttered by the student teachers and then arranged in poetic form to portray the emotional power of their voices. Since we were interested in the student teachers' sense of identity as they transitioned toward becoming teachers, the found poetry offered poignant ways to represent student teachers' beliefs and values. 


\section{Composing Interim Texts-Narrative Accounts}

Narrative accounts were composed from transcripts of interviews held with each student teacher individually at the end of the second APT field placement. They deepened our understanding of the significance of both the ongoing conversations and duration of the field placement experiences at the school. Both the narrative accounts and found poetry were shared with participants and interwoven later with the larger body of field texts.

\section{Composing Research Texts}

Field text data from transcripts as well as interim texts were examined from three main perspectives, a metaphorical three-dimensional narrative inquiry space conceptualized by Clandinin and Connelly (2000). A narrative inquiry space is derived from Dewey's understanding of experience. As such, the framework directs us to inquire into the experience of continuity and interaction while at the same time attending to the situation/place of the experience. In this way we considered student teachers' experiences at the school in relation to their past, present and imagined future lives. We considered the way student teachers were interacting both internally (their feelings) and externally (their outer circumstances). And we considered place, the relational space we created in conversation in the principal's office as having a significant shaping effect on the conversation and stories told. Throughout the study, ongoing conversation amongst ourselves, contributed additional perspectives as patterns arose in the stories. We composed stories to illuminate the themes.

\section{The Inquiry-Belonging}

Drawn from the field texts of student teachers' experiences were two interwoven themes of belonging. The themes are explored here within the context of our main research focus: the exploration of student teachers' experiences in their two field placements held in one particular school community. In this first section, we share stories composed around themes of belonging which were illuminated in the field text data.

The first story picks up the thread of belonging to a teaching story. As student teachers began to connect their past lives through storytelling to the teaching life they were experiencing, their learning became continuous and intertwined, enabling them to feel a sense of belonging and allowing them to grow in educative 
ways (Dewey, 1938). The second story is composed around the idea of belonging to a school and illuminates the significance of place in recognizing a sense of belonging (Basso, 1996). The third story is about a sense of belonging in a teacher education story. The notion of belonging is evoked as aspects of teacher education at the university become connected to and "a part of" the student teachers' lives at school.

\section{Belonging to a Teaching Story}

In conversation, student teachers remembered back to a time when they were learners in school themselves. They recalled experiences in small rural and city schools and their transitions to larger schools. They told stories of particular teachers who mattered and why. They remembered and told stories about positive and negative learning experiences in school. At the same time they talked about their present experiences, viewing school from a teacher's perspective."I know for me I've just been having so many flashbacks, like getting on that bus today ... it's almost like déjà vu, 'cause like I'm on the other side of the desk now" (Group conversation, October 11, 2002).

Being on the "other side of the desk" drew talk and fascination with the way they were perceived by students. One student teacher talked about her grade one students being amazed that she had a mom and dad and that she shopped at Safeway. She wondered about the narrow script of "teacher" being portrayed in the stories of her young students. "You're almost up there on this pedestal. You're not really a person, you're a teacher" (Group conversation, December 11,2002).

Near the end of the second field experience, the same student shared that when she was asked by a student why she didn't know an answer, she replied "and you know like, when I say I don't know, then they're like, oh ... that's because she's a real person" (Group conversation, March 12, 2004).

Over the two field experiences, student teachers shared more and more of their own lives with students, with us and with one another as opportunities arose. Providing time for sustained conversation during the two field placements was enabling student teachers to become more comfortable sharing their past lives and new experiences at the school. We share this excerpt of a found poem from an interim text composed January 2003. 
I'm assimilating all these things at Ravine

Into myself

It gives me a stronger ... what's the word?

Sense of identity

It seemed that student teachers were becoming part of the stories they imagined about becoming teachers.

\section{Belonging to a School}

All the student teachers expressed that returning to the same school for the second field experience led them to believe they were accepted as part of the school community. The emotional connection depicted in the words of one student portrayed for us the significance of belonging to a school.

Sue believes in me

That I can be a good teacher

That I can come back ...

And I got a sense from the staff

And the students

They would like it if I did come back

He told us he gained confidence from getting to know so many teachers. He said that getting to know everybody better was easier over the extended period of time because there was no need to spend time at the beginning of the field placements "just trying to figure out what's going on" (individual interview, January 2003). The student teacher shared later that having the second field experience at the same school meant the most to him in his overall learning in the program. "I wasn't nervous in class at the university two weeks before we went for our APT (advanced practicum term). I knew everyone, all the teachers, and I could ask anyone a question. The teachers were glad to see us. They said they didn't know how they'd do things without us" (Narrative account, May 26, 2004).

Another student teacher talked about the likelihood of teaching in grade levels different than those she experienced in her practicum but said that in being part of a whole school she could come anytime and "ask anyone" a question or borrow resources in the school."I could probably go to anyone in the school and have, and know that like no matter what grade I'm teaching, I can call, I'm teaching grade 
three I can call up Naomi, I can call up Maggie or somebody ..." (Group conversation, April 16, 2004).

For this student teacher, being able to "bond" with the whole school rather than a single cooperating teacher built for her a significant resource to draw on as a beginning teacher. Might offering two field placements at the same school enlarge the opportunity to create such a resource?

\title{
Belonging to a Teacher Education Story
}

One student teacher talked further about being better able to attend to her course work during the time between her first and second field placement because she connected her course work to her experiences at the school, knowing she would return again. We share this excerpt from a found poem composed from an interim text January 2003.

\author{
Yeah! I know where I'm going \\ It's always in the back of my mind \\ Kind of preparing for it in a way \\ I always think about it ... you have something \\ My little work place \\ And when they give assignments \\ I'll try to give my all \\ That goal of having a place to go next time \\ Pulls it all in
}

In another account, a student teacher said: "When I was doing my music classes I could imagine [the school]. I could picture what I could do in that classroom. Whereas I don't think I'd be able to plan out things if I didn't have that" (Narrative account, May 19, 2004).

Might there be a reason to pay more attention, "always think about it," "pull it all in" and "imagine" if student teachers know the place they would be returning to? Might experiencing two field placements at the same school offer student teachers the opportunity to connect their learning on campus to their learning in the field placements through the imaging? 


\section{The Inquiry_-Becoming Teachers}

In the following section we share themes from the field texts that were expressed as student teachers' interaction with children, teachers, administrators and families that grew over the time of two field placements. Inquiry into our field text data shaped complex themes as student teachers grappled with issues associated with diversity and transition, multiplicity, rhythms in teaching, and uncertainty and dilemmas as their lives as becoming teachers unfolded.

Becoming attentive to children's lives is a theme that resonates through all the stories of student teachers becoming teachers. Through the stories we see how they are developing their personal practical knowledge as teachers. That is, we understand them to be developing a sense of what it felt like to be a teacher, cultivating "a moral, affective and aesthetic way of knowing life's situations" (Connelly and Clandinin, 1988, p. 95). The stories here were composed to highlight particular aspects of teaching the student teachers were coming to know.

\section{Coming to Know Diversity and Transition}

Student teachers were struck by the diversity of children and families they were meeting on this school landscape. For one, the contrast triggered memories of her upbringing in Southern Alberta. "Wow, I mean we went to school in white middle class, you know what I mean, everyone's pretty much the same ... but up here it's like ... wow" (Group conversation, October 11, 2002).

She recalled encountering more diverse students when she moved from a small rural school to a larger urban high school but she remembers not really paying attention. "We're all kind of like, look at all the new kids, you know and when we went to high school we still all hung out ... all the little hamlets go to Cardston for high school so there's like the Halsbury kids, the Mountainview kids, and we all kind of stuck together a bit because we've been together for so long" (Group conversation, November 22, 2002). We were curious, it seemed this student teacher didn't attend to diversity during high school.

But now she was facing (Anzaldua, 1990) diverse students head-on in her field placements and the facing seemed to draw a response. "Like you really have to put yourself in their shoes and try and relate to them (Group conversation, March 5, 2004). 
Our weekly conversations became filled with talk around diversity. Student teachers explored issues such as children transitioning to school from more or less structured home situations. They considered the strengths of children whose experiences were different from their own and the need to attend to the wholeness of their lives.

Student teachers remembered times of transition in their past, where differences were encountered in their personal lives. Conversation centred around times in small schools and the transitions to larger schools, and times of transition from elementary to junior high school. One student teacher told stories of particular teachers who eased the transition just by talking with them about the situation they would be experiencing. She remembered these teachers as having respect for them as people. "I remember in grade 6, my teacher spent a long time telling us how ... he was trying to prepare us, if you don't hand in your homework, he showed us on the board, I remember exactly ... he spent a lot of time on that" (Group conversation, March 12, 2004).

We wondered if offering the possibility of relational continuity through sustained dialogue over the two field placements was shaping opportunities for student teachers to negotiate more successfully their own transitions to the new, diverse world they were encountering in the school.

\section{Coming to Know Multiplicity}

One student teacher began to talk about the necessary responsibility and hard work of attending to so many things at once while trying to keep children's lives at the forefront. "And it's just not, just do this, do this, do this. I mean if it was and everybody was just sitting there, you know I mean that would be something. But you're so aware of all the different,...you've got so much going on in your head at all times" (Group conversation, April 8, 2004).

Conversation around multiplicity resonated with one student's experience of playing a musical instrument. "You have to look up, you want to make sure you're breathing properly, you got to be able to read your notes, you got to be able to push the keys down ... interpret the markings on the page and how you want to play the notes, you have to watch the conductor and what the conductor is doing and listen to everybody else to make sure you're playing an appropriate level" (Group conversation, March 19, 2004). 
It seemed student teachers' understanding of teaching, was developing not as a lock-step, linear process of adding more and more skills but rather as an "awakening" (Greene, 1995, p. 28) to the multiplicity of lives and the possibilities for imagining what might be otherwise. For example, a student teacher began to question having only one prescribed, usually academic, route to success for children in school. She began to wonder what success might be in diverse children's lives as well as their own; to imagine a wider story of success. She told of her aunt's work with children experiencing severe difficulties. She related that for her aunt, just making eye contact was a big step (Narrative account from individual interview, May 2004).

We wondered if providing opportunities for relational continuity through sustained conversation over the two field placements was deepening student teachers' knowing of the complexity of becoming a teacher?

\section{Coming to Know Dilemmas and Uncertainty}

As the student teachers' knowing of teaching deepened over time, they began to speak of dilemmas, tensions and uncertainty. One spoke about the tension of attending children's lives amidst the ever-moving school landscape. "I know with this one kid and he came to me and he asked a lot of questions and he continually asked a question and I said, 'Just a minute, I'll be right there,' sort of thing and then I just got so busy doing everything else. And like it was the end of the day and he left ... And that was bad, and oh my gosh ... I felt bad for him because he did come and ask me a question and I told him that I'd be there" (Group conversation, March 19, 2004).

A student teacher admitted he didn't "know everything" even though he felt pressure to know things with certainty. "There's a lot of expectation that you know so much. But really all I have really learned is that ... like you just get, you start, there's so much more" (Group conversation, March 19, 2004).

We wondered, might offering conditions of relational continuity through sustained conversation over two field placements at the same school provide the student teachers with a safe place to bring dilemmas and uncertainty forward, for reflection and learning? 


\section{Coming to Know Rhythms in the School}

Connelly and Clandinin (1988) conceptualize rhythmic knowing as "the way in which we as teachers 'know' the cycles of schooling and come to 'know' when certain cyclical patterns in our narrative of school life will draw out certain images" ( $p$. 76).

Over the period of their two field placements at the same school, student teachers began to feel the rhythm of the school landscape. Our dialogue with student teachers began to reflect this new understanding. Phrases like "getting the hang of it now" and having "a really good presence" and "it really seems to be flowing well this week" (Group conversation, April 8, 2004) cropped up frequently by the end of the second practicum at the school.

Student teachers noticed the children's excitement about spring break, for example, and then the attention needed for the transition time as students reoriented themselves from home to school afterward. One talked of "cutting students some slack" as they felt the rhythm of particular situations. "I've learned there is a certain time to do stuff and a week before spring break is not ..." (Group conversation, March $26,2004)$.

The culture of this particular school was event filled. Every month there was something going on. Over time the idea of "going with the flow" became a way of being at the school because "If you kept putting things off for it to be like, oh, when it gets less crazy ... it never gets less crazy" (Group conversation, May 19, 2004).

Student teachers began to recognize "teachable moments" and would be ready to shift lessons in favour of learning as response to a particular question or need at the time. One student teacher noted "I find that the more and more that I teach them, I'm worried less and less about getting to page 81 today ... like I found out the other day when I asked them about time and they couldn't tell me ... and so I just dropped everything I was doing and taught them about time" (Group conversation, March 26, 2004).

We pondered if creating opportunities for relational continuity through sustained dialogue over the two field placements contributed to student teachers' attention and knowing of the rhythm in their own lives, in their students' lives and in the life of their particular school. Also, we wondered if knowing about the rhythmic nature of lives in school contributed to a more responsive and improvisatory way of teaching in a school. 


\section{Teachers as Curriculum Makers}

Although curriculum planning was shaped by mandated policies that student teachers were obligated to adhere to, the reflective space of sustained conversation within two field experience placements at the same school over time created openings for student teachers to shape the way curriculum would unfold.

Narrative understandings of teaching embodied in personal philosophies and principles (Connelly and Clandinin, 1988) began to guide one student in her planning as a teacher. "Our discussions and stuff, it's really opened ...opened up our thoughts as to what our philosophies are about teaching, just from the discussions we've had ..." (Individual interview, January 24, 2003).

Another student teacher talked about our weekly conversations as being a time to think about school and education as a whole. "For me it was most helpful to have the conversations. Whatever came up, came up. It was a whole range of issues we talked about in our conversations" (Narrative account from individual interview, May 26, 2004).

At the end of the two field placements a student teacher stated that she felt "the philosophy of the principal is key," that there is a lot of "hidden curriculum" and there's "a lot of politics in schools." She commented that the conversations helped her "really think about what she was doing" in school (Narrative account from individual interview, May 19, 2004).

We wondered if being listened to, through the course of the two field placements at the same school was enabling these student teachers to develop their individual voices and a sense of agency in the curriculum-making process with the children as Connelly and Clandinin (1988) have described.

\section{Reflection}

For us as participants in this narrative inquiry, we not only considered the longer time frame and sustained conversation from which student teachers shaped their knowing as they were becoming teachers, but we also noted the place of our conversations-the principal's office. Although the student teachers had chosen willingly to be part of the study, we acknowledge the inherent power differential that exists between student teachers and the principal. The conversations in the 
principal's office were however not agenda driven, rather the focus was the student teachers' evolving lives. Might this shift in attention towards the students' unfolding lives have shaped a safer place for conversations to evolve?

Richardson (1997) writes that the kind of conversation we have shapes the kind of communities we become. "Communication as 'community' invites participation, association, locale, temporality entrustment and most important, empathy. It privileges human agency" (p. 79). We wondered if positioning our weekly conversations in the principal's office might have shaped a broader sense of belonging and agency for these student teachers in school and education as a whole?

We wondered if the way conversation happened in the principal's office encouraged and helped to build leadership capacity (Lambert, 1998) in new teachers. Constructing a situation in which student teachers were invited to share their teaching experiences, past, present and imagined future, directed the course of conversation. Student teachers initiated comments and questions about their experiences. As more experienced educators we listened, and frequently responded with comments of our own, often connecting ideas to the educational literature and research during teachable moments as they arose. We are reminded of Oyler's work around shared authority (1996) where students in a classroom were not positioned as passive receptors of teacher-driven content but rather joined with the teacher to be co-constructors in learning. Oyler suggests the following for students:

[They] be given ample time to connect and extend the understandings from texts with their own lives. For it is by initiating that we can act upon the world and speak as experts, claiming authority, even if we are poor (p. 148).

Oyler was talking about students in a classroom, but we wonder if sharing authority for conversation in a principal's office can help to develop leadership capacity in a school.

When we listened to Linda's story, the tension we were feeling crystallized as we laid her story alongside the stories of the student teachers in our study. Indeed, we agree with Bateson (1994) who helps us see that, "Insight, I believe, refers to that depth of understanding that comes by setting experiences, yours and mine, familiar and exotic, new and old, side by side, learning by letting them speak to one another" (p. 14). We realize what might have been for Linda was the missing relational thread that might have led to educative possibilities for her life. 


\section{Conclusion}

Teacher education and becoming a teacher is continuous over a lifetime (Vinz, 1996; Hollingsworth, 1993). Students do not graduate from teacher education programs "fully formed" as teachers. They can only continue to become teachers over time. But what direction might help them move foward? This inquiry makes us wonder ... if student teachers begin to experience their own lives as composed in a situation of relational continuity, might they begin to know teaching as something about composing lives, their own and those of children, teachers, principals and families living on school landscapes (Clandinin et al., 2006)?

The inquiry portrayed the significance of belonging to one school landscape over a sustained period so that that student teachers could imagine themselves teachers during their field placements. Sustained conversation through regularly scheduled meetings provided a space for the development of trusting relationships and longer- term reflection. This enabled student teachers, as well as ourselves, to tell and retell our knowing as educators. Lyons (1998) has noted in her work with beginning teachers the significance of reflection over time, rather than in connection to single incidents or contexts.

The themes of belonging and becoming cut across the student teachers' experiences. Both threads became visible to us as student teachers expressed their understandings of their experiences at the school. Belonging was expressed in narrative themes around connected learning and identity. Student teachers connected their own lives with a teaching story, a school story and a teacher education story. We found that as student teachers experienced their lives while being attended to as people, a sense of belonging emerged; at the same time their attention turned toward lives in school, the children's, teachers and administrators and others, the families and themselves. The idea of becoming was expressed in themes of coming to know diversity and transition, multiplicity, rhythms in teaching and dilemmas and uncertainty. As student teachers experienced being "really listened to" (Belenky et al., 1986) in sustained conversation over time, they began to weave together threads of belonging and becoming to create their own "ways of knowing," as "curriculum planners" (Connelly and Clandinin, 1988).

As student teachers explored and talked about things that really mattered to them, their engagement with the school both broadened and deepened giving rise to more careful noticing and more sensitive responsiveness. As student teachers' imaginations were triggered in conversations, new ways of knowing and 
seeing emerged. Student teachers began to acknowledge diversity and transition, multiplicity and the rhythmic cycles of school (Greene, 1994). They recognized the dilemmas and uncertainty involved in becoming teachers.

Dialogue embodies the true relation in education (Buber, 1947), In this study it provided a way of working in relationship over two field placements and created a condition of relational continuity for student teachers. By creating a situation of relational continuity in student teacher field placements, student teachers were able to connect their life experiences with their new experiences at the school. The ongoing dialogue and mentoring that occurred in teachable moments helped to build a sense of agency and leadership capacity among these student teachers.

\section{References}

Anzaldua, G. (1990) (Ed.). Making face, making soul, Haciendo caras: Creative and critical perspectives by feminists of color. San Francisco: aunt lute books.

Basso, K. (1996). Wisdom sits in places. In S. Feld \& K. Basso (Eds.), Senses of Place (pp. 33-90). New Mexico: School of American Research Press.

Bateson, M.C. (1994). Peripheral visions: Learning along the way. New York: Harper Collins.

Belenky, M. F., Clinchy, B., Goldberger, N. \& Tarule, J. (1986). Women's ways of knowing: The development of self, voice, and mind. New York: Basic Books.

Buber, M. (1947). Between man and man (R. G. Smith, Trans.). London: Collins.

Butler-Kisber, L. (1998, April). Representing qualitative data in poetic form. Paper presented at the Annual Meeting of the American Educational Research Association, San Diego, CA.

Clandinin, D.J., Huber, J., Huber, M., Murphy, M.S., Murray Orr, A. Pearce, M., \& Steeves, P. (2006). Composing diverse identities. Narrative inquiries into the interwoven lives of children and teachers. London: Routledge.
Clandinin, D.J. \& Connelly, F. M. (2000). Narrative Inquiry: Experience and story in qualitative research. San Francisco: Jossey-Bass.

Clandinin, D. J., Davies, A., Hogan, P., \& Kennard, S. (1993) (Eds.). Learning to teach, teaching to learn: Stories of collaboration in teacher education. New York: Teachers College Press.

Coles, R. (1989). The call of stories: Teaching and the moral imagination. Boston: Houghton Mifflin.

Connelly, F.M. \& Clandinin, D.J. (1988). Teachers as curriculum planners: Narratives of experience. New York: Teachers College Press.

Connelly F. M. \& Clandinin, D. J. (1999). Shaping a professional identity: Stories of educational practice. New York: Teachers College Press.

Dewey, J. (1938). Experience and education. New York: Macmillan.

Greene, M. (1995). Releasing the imagination. San Francisco: Jossey-Bass Publishers.

Hollingsworth, S., Dybdahl, M. \& Minarik, L. (1993). "By chart and chance and passion: The importance of relational knowing in learning to teach." Curriculum Inquiry, 23(1), 5-35. 
Lambert, L. (1998). Building leadership capacity in schools. Virginia: Association for Supervision and Curriculum Development.

Lyons, N. (1998). "Reflection in teaching: Can it be developmental? A portfolio perspective." Teacher Education Quarterly, 25(1), 115-127.

Oyler, C. (1996)."Sharing authority: Student initiations during teacher-led read-alouds of information books." Teaching and Teacher Education, 12(2), 149-160.

Paley, V. (1986). "On listening to what the children say" Harvard Educational Review, 56(2), 122-131.
Richardson, L. (1997). Fields of play: Constructing an academic life. New Jersey: Rutgers University Press.

Steeves, P. (2000). Crazy Quilt: Continuity, identity and a storied school landscape in transition: A teacher's and a principal's work in progress. Unpublished doctoral dissertation, University of Alberta, Edmonton.

Vinz, R. (1996). Composing a teaching life. Portsmouth, N.H: Boynton/Cook.

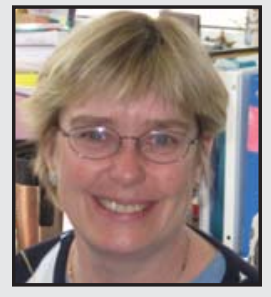

Sue McKenzie-Robblee, M.Ed. As an elementary school principal with Edmonton Public schools for over 21 years, Sue has been involved with many different kinds of alternative teacher education programs. She has a continuing interest in teacher education, for both practicing and pre-service teachers with a focus around identity and reflective practice. Sue works with staff, consultants and parents to create school experiences for children that celebrate differences and honor the ways in which children learn, grow and develop their sense of who they are as learners.

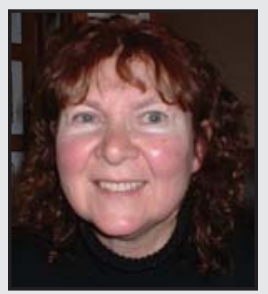

Pam Steeves, Ph.D. Since completing her Ph. D., a narrative inquiry concerned with composing identity during experiences of transition on school landscapes, Pam has continued her association with the Centre for Research for Teacher Education and Development at the University of Alberta, currently as an Assistant Adjunct Professor. Pam's interests evolve from inquiries around the relational nature of identity making over time and the place of imagination and response in composing lives. 